Acta Universitatis Nicolai Copernici • Pedagogika XLII/2/2021

Nauki Humanistyczno-Społeczne • Zeszyt 454

DOI: http://dx.doi.org/10.12775/AUNC_PED.2021.021

\author{
Beata Topij-Stempińska \\ Instytut Nauk o Wychowaniu \\ Akademia Ignatianum w Krakowie \\ ORCID: 0000-0002-4257-5844
}

\title{
MATERIAE ŹRÓDŁOWY \\ w MuZeum OKręgowym w SANDOMIERzU* DO ŻYCIA I DZIAŁALNOŚCI OŚWIATOWEJ \\ Aleksandra K. Patkowskiego (1890-1942) \\ Przyczynek do badań
}

Sources Related to the Life and Educational Work of Aleksander K. Patkowski (1890-1942) that Can Be Found in the District Museum in Sandomierz. The contribution to research

\begin{abstract}
Streszczenie
Aleksander K. Patkowski związany był z Sandomierzem przez całe swoje życie. Najpierw tu mieszkał z rodzicami, uczył się i pracował w sandomierskich szkołach, aktywnie uczestniczył w życiu społeczności lokalnej. Później po wyjeździe do Warszawy nadal interesował się Sandomierzem, a nawet szerzej regionem sandomierskim. Wielu badaczom znany jest przede wszystkim

* Składam podziękowania pracownikom Działu Literatury Muzeum Okręgowego w Sandomierzu - Pani Elżbiecie Kownackiej i Pani Annie Kowalskiej-Różyło za umożliwienie oraz pomoc w przeprowadzeniu kwerendy.
\end{abstract}


jako „ojciec regionalizmu polskiego”. To właśnie w Sandomierzu z jego inicjatywy powołano Powszechny Uniwersytet Regionalny (1923 rok). Aktywnie uczestniczył w wydarzeniach związanych z popularyzacją wiedzy dotyczącą regionu, ale także edukacji dorosłych. $\mathrm{W}$ rodzinnym mieście Patkowskiego m.in. w Dziale Literatury Muzeum Okręgowego w Sandomierzu gromadzone są i przechowywane archiwalia związane z życiem i działalnością Patkowskiego. Zatem dla podjętych rozważań istotne jest pytanie: Jaki materiał źródłowy zgromadzony został w Muzeum Okręgowym w Sandomierzu? oraz które ze zgromadzonych archiwaliów pozwolą na uzupełnienie wiedzy dotyczącej życia i działalności oświatowej Patkowskiego?

Słowa kluczowe: materiał źródłowy, Muzeum Okręgowe w Sandomierzu, Aleksander K. Patkowski, działalność oświatowa, „ojciec regionalizmu polskiego".

\begin{abstract}
Aleksander K. Patkowski was related to Sandomierz for all his life. First he lived there with his parents, he studied and worked in Sandomierz schools, and he actively participated in the local society's life. Then, after leaving for Warsaw, he was still interested in Sandomierz and the surrounding region. In the scientific environment he is known as "the father of Polish regional studies". It was his idea to open the Public Regional University (1923) in Sandomierz. Patkowski participated in various initiatives aimed at promoting the knowledge of the region, as well as education of adults. In his hometown, e. g. in the Department of Literature of the District Museum in Sandomierz, we can find many documents related to his life and scientific activity. Thus, the following questions are important for our considerations: What sources can be found in the District Museum in Sandomierz? Which of the archives will make it possible to extend our knowledge concerning the life and educational activity of Patkowski?
\end{abstract}

Kay words: sources, District Museum in Sandomierz, Aleksander K. Patkowski, educational activity, „father of Polish regional studies”. 


\section{Wprowadzenie}

Materiały źródłowe są dla badacza przeszłości nieodzownym elementem poznawania minionych czasów, przeszłych wydarzeń oraz życia ludzi. Stanowią swoistego rodzaju pomost łączący przeszłość z teraźniejszością. Dzięki dokumentom źródłowym możliwe jest poznanie jakiegoś wycinka historii, również tej lokalnej czy po prostu historii życia i działalności konkretnej postaci. W przypadku badań dotyczących biografii istotne znaczenie mogą mieć dokumenty osobiste tzw. ego dokumenty' ${ }^{1} \mathrm{~W}$ archiwalnych zasobach przechowywane mogą być zarówno dokumenty urzędowe oraz prywatne, jak również pamiętniki, dzienniki, życiorysy, korespondencja oraz inne materiały. Dokumenty takie często związane są z życiem codziennym, ale także z pracą zawodową postaci. Należy podkreślić, że archiwa i inne instytucje zajmujące się gromadzeniem dokumentów osobistych są „prawdziwymi skarbnicami”, bowiem „kryją w swych zasobach niezwykłe bogactwo dowodów pamięci historycznej"2. Zanim przejdę do przybliżenia zbiorów dotyczących Aleksandra Kazimierza Patkowskiego znajdujących się w Dziale Literatury Muzeum Okręgowego w Sandomierzu, w krótkim szkicu przypomnę sylwetkę tego zasłużonego regionalisty, ale także nauczyciela i działacza oświatowego.

\section{1. Życie i działalność oświatowa Aleksandra Patkowskiego}

Aleksander Kazimierz Patkowski urodził się 4 marca 1890 roku w Ożarowie w rodzinie Heleny i Leona Patkowskich ${ }^{3}$. W 1899 roku rodzice Patkowskiego przeprowadzili się do Sandomierza, gdzie ojciec podjął pracę lekarza powiatowego. W Sandomierzu rozpoczęła się również

1 W. Szulakiewicz, Ego-dokumenty $i$ ich znaczenie $w$ badaniach naukowych, „Przegląd Badań Edukacyjnych” 2013, nr 16, s. 67.

2 Tamże, s. 80.

3 S. Łoza, Czy wiesz kto to jest?, Wydawnictwo Głównej Księgarni Wojskowej, Warszawa 1938, s. 557-558. 
droga edukacyjna Aleksandra. W latach 1899-1904 był uczniem progimnazjum w Sandomierzu. Jednak już w 1904 roku Aleksander musiał opuścić Sandomierz, naukę kontynuował w Warszawie, najpierw w V gimnazjum, a następnie w prywatnym gimnazjum gen. Pawła Chrzanowskiego (Zakład Naukowo Filologiczny 8-klasowy) w Warszawie. Po zdanej w 1908 roku maturze, wyjechał na studia do Galicji, do Lwowa. W Uniwersytecie Lwowskim, a następnie w Uniwersytecie Jagiellońskim studiował filologię klasyczną, polonistykę i anglistykę. Absolutorium uzyskał 27 października 1913 roku$^{4}$. W okresie szkolnym i studenckim przyjeżdżał do Sandomierza na wakacje i aktywnie włączał się w działania na rzecz społeczności lokalnej, m.in. organizując i biorąc aktywny udział w przedstawieniach teatralnych, z których dochód przeznaczony był na cele społeczne ${ }^{5}$. Na stałe powrócił do Sandomierza w 1915 roku i jedną z jego pierwszych inicjatyw było współorganizowanie polskiego gimnazjum, w którym rozpoczął pracę w charakterze nauczyciela. Był „nauczycielem na miarę”, nie tylko pobudzał, zachęcał uczniów do poszerzenia wiedzy na swoich lekcjach, ale także aktywizował na różnorodnych polach. Zakładał i prowadził kółka literackie, teatralne, spółdzielnię uczniowską, samorząd szkolny. Zachęcił uczniów do prowadzenia szkolnej gazetki „Spójnia”6. Jeden z jego uczniów tak go wspominał: „Cała nasza edukacja społeczna przebiegała w cieniu osobowości Aleksandra Patkowskiego (...). Był pełen energii, życia, humoru i nieskończonej dobroci. Kochaliśmy wtedy wszystkich naszych wychowawców, ale Patkowski był nie tylko wychowawcą, ale był również starszym kolegą i przyjacielem"7. Patkow-

4 Corpus studiosorum Universitatis Iagellonicae in saeculis XVIII-XX, t. 3, O-Q, red. K. Stopka, Kraków 2011, s. 234.

${ }^{5}$ Program przedstawienia amatorskiego na rzecz Sandomierskiego Towarzystwa Dobroczynności 1908 r., Muzeum Okręgowe w Sandomierzu, Dział Literatury, syg. 786/2. [dalej: MOS DL]

6 Z. Wójcik, Aleksander Patkowski pionier regionalizmu turystyczno-krajoznawczego $w$ Polsce, Radom 2003, s. 25; P. Sławiński, Sandomierskie lata Aleksandra Patkowskiego, w: Twórca polskiego regionalizmu. Nowe badania nad życiem i działalnością Aleksandra Patkowskiego, red. T. Giergiel, Sandomierz 2015, s. 108-109.

7 A. Bień, Bóg wysoko-dom daleko: obrazy przeszłości 1900-1920, Warszawa 1984, s. 314. 
ski angażował się nie tylko w życie szkole uczniów, ale także aktywnie uczestniczył w organizacji społeczności nauczycielskiej. To w tym mieście w 1916 roku zorganizował Zrzeszenie Nauczycielstwa Szkół Początkowych, które to w 1919 roku przekształcone zostało na sandomierski oddział Związku Nauczycielstwa Polskiego Szkół Powszechnych. Natomiast w 1917 roku współorganizował Spółdzielczą Księgarnię Nauczycielską „Ognisko” i przewodniczył jej zarządowi do 1924 roku. W sandomierskich szkołach (liceum, seminarium nauczycielskie) pracował do 1923 roku.

Ważnym wydarzeniem w historii miasta i działalności na polu oświatowym Patkowskiego było zorganizowanie kursów wakacyjnych dla nauczycieli w 1922 roku, a na ich podbudowie powołanie Powszechnego Uniwersytetu Regionalnego ${ }^{8}$, który miał popularyzować idee regionalizmu, a także samokształcenia dorosłych. Po przeprowadzce do Warszawy Patkowski nie zapomniał o Sandomierzu, nadal uczestniczył w wydarzeniach związanych z popularyzacją wiedzy o Sandomierzu i jego okolicach, współorganizował kursy wakacyjne dla nauczycieli, wygłaszał liczne odczyty. W Warszawie podjął pracę najpierw w Towarzystwie Urządzeń Szkolnych i Laboratoryjnych „Urania”. Prowadził również wykłady dla słuchaczy w Państwowym Wyższym Kursie Nauczycielskim. W 1928 roku otrzymał stanowisko radcy w Ministerstwie WRiOP, gdzie był zatrudniony aż do 1939 roku'. Powierzono mu m.in. sprawy związane z oświatą pozaszkolną. Czas okupacji to trudny okres dla Patkowskich. Rodzina borykała się z wieloma problemami brakiem żywności, pieniędzy, opału, kłopotami zdrowotnymi córki. Latem 1940 roku Aleksander otrzymał pomoc i zatrudnienie. Jednak już w styczniu 1941 roku został aresztowany i wywieziony do Auschwitz, gdzie zmarł w 1942 roku $^{10}$.

8 E. Szylko, Działalność Powszechnego Uniwersytetu Regionalnego im. St. Konarskiego Związku Nauczycielstwa Polskiego w latach 1922-1930, w: Pamiętnik Świętokrzyski 1930, red. A. Patkowski, Kielce 1931, s. 401-403.

9 A. Rembalski, Z. Wójcik, Aleksander Patkowski, w: Polski słownik biograficzny, t. 25, Wrocław-Warszawa-Kraków-Gdańsk 1980, s. 332-334.

10 P. Banaczkowski, Aleksander Patkowski. Zarys życia i pracy, w: A. Patkowski, Whołdzie dla ziemi rodzinnej, Warszawa 1958, s. 17-18. 
Aleksander Patkowski w opinii wielu badaczy był przede wszystkim regionalistą, jednak, jak zauważył Tomisław Giergiel, jego droga zawodowa związana była z zawodem nauczycielskim: „W latach 1916-1923 pracował jako profesor szkół średnich, a po rezygnacji z etatu nauczycielskiego, do końca życia działał w oświacie pozaszkolnej i uważał się za pedagoga"11.

\section{Stan i potrzeby badań nad życiem i działalnością Aleksandra Patkowskiego}

Postać Aleksandra K. Patkowskiego, jak zaznacza Piotr Sławiński, „jest nietuzinkowa i na jego temat ukazało się wiele publikacji"12. Opinię tę potwierdzają liczne publikacje, które można ująć w trzech kategoriach: biograficznej, regionalnej oraz pedagogicznej. I o ile dwie pierwsze kategorie są dobrze zbadane i udokumentowane, o tyle problematyka związana z działalnością oświatową Patkowskiego podejmowana była przez niewielu badaczy.

Pierwsze publikacje dotyczące osoby Patkowskiego ukazały się jeszcze w latach 40. W 1945 roku Piotr Banaczkowski przypomniał postać Patkowskiego czytelnikom czasopisma „Ziemia”, a Wacław Borowy w 1946 roku na łamach „Pamiętnika Literackiego” opublikował tekst upamiętniający przyjaciela ${ }^{13}$. Kolejne biografie Patkowskiego publikowano na łamach czasopism i prasy lokalnej m.in. „Ziemia Kielecka” (1956), „Studia Kieleckie” (1975), „Notatnik Sandomierski” (1995) oraz „Ożarów” (2000) ${ }^{14}$, a także innych publikacjach. W tym miejscu warto

11 T. Giergiel, Dziedzictwo przodków. Pochodzenie Aleksandra Patkowskiego, w: Twórca polskiego regionalizmu. Nowe badania nad życiem i działalnościa Aleksandra Patkowskiego, red. T. Giergiel, Sandomierz 2015, s. 96.

12 P. Sławiński, Sandomierskie lata Aleksandra Patkowskiego, w: Twórca polskiego regionalizmu. Nowe badania nad życiem i działalnością Aleksandra Patkowskiego, red. T. Giergiel, Sandomierz 2015, s. 101.

13 P. Banaczkowski, Aleksander Patkowski, „Ziemia”, 1945 nr 1-2, s. 4-5; W. Borowy, Aleksander Patkowski, „Pamiętnik Literacki”, 1946 nr 3-4, s. 309-312.

14 P. Banaczkowski, Aleksander Patkowski, „Ziemia Kielecka”, 1956 nr 1, s. 3;

I. Bednarz, Aleksander Patkowski (1890-1942, „Studia Kieleckie”, 1975 nr 3, s. 89-92; M. Łowicka, Portret Aleksandra Patkowskiego, „Notatnik Sandomierski”, 
wspomnieć o biogramie Patkowskiego opublikowanym w Polskim słowniku biograficznym. Hasło biograficzne poświęcone Patkowskiemu zamieszczone są również w Leksykonie historii Polski, Słowniku biograficznym prekursorów turystyki oraz działaczy PTT, PTK i PTTK, a taki̇e $w$ Słowniku pracowników ksiązki polskiej. Ponadto artykuły biograficzne zamieszczano w wydawnictwach okolicznościowych czy jubileuszowych. I tak Piotr Banaczkowski, w wydanym w 1958 roku zbiorze artykułów Patkowskiego pt. W hołdzie dla ziemi rodzinnej, publikuje tekst poświęcony życiu i pracy Aleksandra Patkowskiego. Również autorzy publikacji wydanej z okazji setnej rocznicy urodzin sandomierzanina, zamieścili artykuł przypominający sylwetkę i dokonania Patkowskiego, natomiast lata życia i pracy w Sandomierzu przybliża Piotr Sławiński w wydanej w 2015 roku publikacji zbiorowej pod red. Tomisława Giergiela ${ }^{15}$. We wspominanej publikacji zamieszczono także artykuł pt. Aleksander Patkowski mniej znany, ukazujący postać Patkowskiego w świetle korespondencji z rodzicami ${ }^{16}$. Najliczniejszą grupę publikacji stanowią te poruszające problematykę regionalizmu $\mathrm{w}$ poglądach

1995 nr 7, s. 32-37; W. Lipowski, Wspomnienie o Patkowskim, „Ożarów”, 2000 nr 4, s. 20-21.

${ }^{15}$ A. Rembalski, Z. Wójcik, Aleksander Patkowski, w: Polski słownik biograficzny, t. 25, Wrocław-Warszawa-Kraków-Gdańsk 1980, s. 332-334; M. Czajka, M. Kamler, W. Sienkiewicz, Patkowski Aleksander, w: Leksykon historii Polski, Warszawa 1995, s. 550; Patkowski Aleksander, w: Stownik biograficzny prekursorów turystyki oraz działaczy PTT, PTK i PTTK, Warszawa 1988; S. Wojciechowski, Patkowski Aleksander Kazimierz, w: Stownik pracowników książki polskiej, Warszawa-Łódź 1972, s. 662; P. Banaczkowski, Aleksander Patkowski. Zarys życia i pracy, w: A. Patkowski, W hołdzie dla ziemi rodzinnej, Warszawa 1958; s. 11-39; J. Grzywna, J. Jadach, Aleksander Patkowski (1890-1942), w: W hołdzie Aleksandrowi Patkowskiemu (w setna rocznice urodzin), red. J. Grzywna, A. Rembalski, Kielce 1991, s. 6-17; P. Sławiński, Sandomierskie lata Aleksandra Patkowskiego, w: Twórca polskiego regionalizmu. Nowe badania nad życiem i działalnością Aleksandra Patkowskiego, red. T. Giergiel, Sandomierz 2015, s. 101-121.

${ }^{16}$ D. Paszkowska, Aleksander Patkowski mniej znany, w: Twórca polskiego regionalizmu. Nowe badania nad życiem i działalnością Aleksandra Patkowskiego, red. T. Giergiel, Sandomierz 2015, s. 123-135. Skróconą wersję artykułu autorka zamieściła w publikacji wydanej w 2016 r.: D. Paszkowska, Aleksandra Patkowskiego rozmowy z Matuśka, w: Hieronimki, Sandomierz 2016, s. 63-69. 
i działalności sandomierzanina. Wśród wielu prac dokumentujących tę problematykę można wymienić np.: J. Braun, Regionalizm Aleksandra Patkowskiego, „Ziemia”, 1966, s. 31-38; A. Rembalski, Wkład Aleksandra Patkowskiego $w$ rozwój turystyki i krajoznawstwa, w: W hołdzie Aleksandrowi Patkowskiemu (w setna rocznice urodzin), red. J. Grzywna, A. Rembalski, Kielce 1991, s. 53-61; D. Koźmian, Regionalizm w poglądach społeczno-pedagogicznych Aleksandra Kazimierza Patkowskiego (1890-1942) i jego aktualność, „Przegląd Historyczno-Oświatowy”, $2000 \mathrm{nr}$ 1-2, s. 43-52; Z. Wójcik, Aleksander Patkowski pionier regionalizmu turystyczno-krajoznawczego $w$ Polsce, Radom 2003; A. Lubczyńska, Krajoznawstwo i regionalizm $w$ pogladach Aleksandra Patkowskiego, w: Twórca polskiego regionalizmu. Nowe badania nad życiem i działalnością Aleksandra Patkowskiego, red. T. Giergiel, Sandomierz 2015, s. 11-21. Należy zaznaczyć, że wzmianki o działalności Patkowskiego związanej z popularyzacją regionalizmu, krajoznawstwa i turystki odnajdziemy w takich publikacjach, jak: Środowisko historyczne II Rzeczypospolitej, cz. 2, red. J. Maternicki, Warszawa 1987; Dzieje Sandomierza 1918-1980, t. 4, red. W. Czajka, H. Samsonowicz, Warszawa 1994 oraz J. Grzywna, Wkład Związku Nauczycielstwa Polskiego $w$ rozwój regionalizmu $w$ okresie międzywojennym, „Zeszyty Naukowe Muzeum Wsi Radomskiej", 1987 t. 2, s. 29-40.

Podstawową publikacją związaną z problematyką pedagogiczną jest monografia autorstwa Danuty Koźmian pt. Poglady społeczno-pedagogiczne Aleksandra Kazimierza Patkowskiego (1890-1942), Szczecin 1994. Należy zaznaczyć, że jest to jedyna większa publikacja poświęcona kwestiom pedagogicznym. Ponadto wspomniana autorka opublikowała jeszcze jeden artykuł, w którym przybliżyła koncepcję oświaty pozaszkolnej na tle regionalizmu. Inni badacze, m.in. Tadeusz Jałmużna, Wiesław Jamrożek i Dorota Żołądź-Strzelczyk skoncentrowali się na ukazaniu przede wszystkim edukacji regionalnej w ujęciu Aleksandra Patkowskiego ${ }^{17}$.

17 D. Koźmian, Oświata pozaszkolna na tle założeń regionalizmu Aleksandra Patkowskiego (1890-1942), w: Z praktyki polskiej teorii i praktyki andragogicznej, red. E. Sapia-Drewniak, A. Stopińska-Pająk, Toruń 1997, s. 168-181; T. Jałmużna, Aleksander Patkowski - regionalizm i wychowanie społeczne, w: Pokój jako 
Wymienione powyżej publikacje nie wyczerpują podjętego tematu. Pomagają określić dotychczasowy stan badań nad życiem i działalnością Aleksandra Patkowskiego. Najczęściej autorzy wspomnianych (i nie tylko) publikacji korzystali z dostępnych źródeł drukowanych, tj. publikacji Patkowskiego wydawanych na łamach czasopism m.in. „Głosu Nauczycielskiego”, „Ziemi”, „Polskiej Oświaty Pozaszkolnej”18. Autorzy przeprowadzili również kwerendy zasobów archiwalnych w Bibliotece Narodowej, gdzie przechowywany jest życiorys Patkowskiego, napisany przez niego w 1932 roku oraz m.in. korespondencja Patkowskiego do Wacława Borowego. Ponadto kwerendy przeprowadzono w Archiwum Biblioteki Jagiellońskiej, Archiwum Akt Nowych w Warszawie, Państwowym Archiwum w Sandomierzu, a także w niewielkim zakresie w Muzeum Okręgowym w Sandomierzu. I jak zauważyli w 1991 roku Józef Grzywna i Jan Jadach, „źródła dotyczące życia i działalności Patkowskiego są rozproszone, natomiast archiwalia nie zostały w pełni spenetrowane"19. Po ponad dwudziestu latach niewiele się zmieniło, wprawdzie napisano, wspomniane już wcześniej, dwie monografie poświęcone działalności Patkowskiego oraz liczne prace przyczynkarskie, nadal jednak nie powstała biografia Patkowskiego dokumentująca w pełni jego życie i działalność, prowadzoną przecież na wielu polach. Miejscem, w którym przechowywane są archiwalia związane z osobą Patkowskiego, jest obok wyżej wymienionych Dział Literatury Muzeum Okręgowego w Sandomierzu.

przedmiot badań społecznych i pedagogicznych, red. W. Leżańska, T. Jałmużna, Łódź 2006, s. 106-111; D. Żołądź-Strzelczyk, W. Jamrożek, Edukacja regionalna $w$ ujęciu Aleksandra Patkowskiego, w: Edukacja regionalna, red. A.W. Brzezińska, A. Hulewska, J. Słomska, Warszawa 2006, s. 115-130.

${ }^{18}$ Szczegółowa bibliografia prac Patkowskiego zamieszczona została w publikacjach z 1958 r. (s. 293-303) i 2003 r. (s. 96-114).

19 J. Grzywna, J. Jadach, Aleksander Patkowski (1890-1942), w: W hołdzie Aleksandrowi Patkowskiemu (w setna rocznicę urodzin), red. J. Grzywna, A. Rembalski, Kielce 1991, s. 15. 


\section{Muzeum Okręgowe w Sandomierzu i Dział Literatury. Zarys historii}

5 maja 1921 roku uroczyście otwarto w Sandomierzu Muzeum Ziemi Sandomierskiej. Pomysłodawcami i inicjatorami byli członkowie sandomierskiego Oddziału Polskiego Towarzystwa krajoznawczego - Stanisław Karpowicz, ks. Andrzej Wyrzykowski, Józef Pietraszewski i Zdzisław Lenartowicz. W Sprawozdaniu PTK z działalności w roku 1921 podano, że w posiadaniu Muzeum znajdują się 1384 przedmioty, głównie $\mathrm{z}$ archeologii $\mathrm{i}$ etymologii ${ }^{20}$. Zbiory systematycznie powiększano, w pierwszym okresie działalności Muzeum przechowywano je w prywatnych domach członków Towarzystwa. Dopiero w 1925 roku możliwe było przeniesienie eksponatów do nowej siedziby Muzeum. Zbiory gromadzone w Muzeum miały przede wszystkim charakter regionalny. Pierwszym kustoszem muzeum mianowano Leona Wilkońskiego (1927-1939), który uporządkował i zinwentaryzował zbiory ${ }^{21}$. Jego pracę na rzecz muzeum docenił Ludwik Sawicki, podkreślając w rocznym sprawozdaniu z działalności Muzeum jego zaangażowanie w „sprawie tego muzeum i którego zasługi, jako opiekuna zbiorów oraz rzecznika ich potrzeb w łonie Zarządu Oddziału sąbardzo poważne"22. W czasie II wojny Muzeum straciło wiele cennych eksponatów. Po wojnie wznowiono działalność Muzeum dopiero w 1956 roku. Na mocy zarządzenia „nr 46 ministra kultury i sztuki z dnia 18 kwietnia 1956 roku zostało utworzone Muzeum w Sandomierzu"23. Od momentu powołania Muzeum pracownicy kontynuowali prace poprzedników, powiększali i gromadzili zbiory, organizowali wystawy, spotkania i prelekcje. Dynamiczny rozwój Muzeum rozpoczyna się w 1976 roku. Przyczyniła się do tego decyzja wojewody tarnobrzeskiego, który nadał placówce status Muzeum Okręgowego. „Powstają nowe działy: Archeologii, Etno-

20 Sprawozdanie z działalności w roku 1921, Warszawa 1922, s. 12.

21 K. Załuska, Historia Muzeum w Sandomierzu, „Rocznik Muzeum Świętokrzyskiego" 1968 nr 5, s. 13.

22 L. Sawicki, Muzeum P.T.K. w Sandomierzu, „Ziemia”, 1930 nr 15-18, s. 339.

23 K. Załuska, Historia Muzeum w Sandomierzu, „Rocznik Muzeum Świętokrzyskiego" 1968 nr 5, s. 16. 
grafii, Historii, Sztuki, Pracownia Dokumentacji Fotograficznej i Naukowo-Oświatowy"24. Natomiast Dział Literatury funkcjonuje w strukturze Muzeum Okręgowego w Sandomierzu od 2002 roku. Jego korzenie związane są z powołaniem do życia w 1980 roku Oddziału Literatury, przekształconego następnie w 1981 roku w Muzeum Literatury Oddział Muzeum Okręgowego w Sandomierzu. Do zadań nowo powołanego Oddziału, a później Muzeum Literatury należało przede wszystkim „badanie życia i twórczości J. Iwaszkiewicza, ze szczególnym uwzględnieniem związków pisarza z Sandomierzem i jego okolicami"25, jak również gromadzenie zbiorów związanych z pisarzami i twórcami pochodzącymi z Sandomierza i jego okolic, niewątpliwie należał do nich również Aleksander K. Patkowski ${ }^{26}$. Pierwszy kierownik Oddziału Jerzy Krzemiński już w 1981 roku pozyskał dla placówki dokumenty związane z osobą Patkowskiego. Jerzy Krzemiński pamięta, że dokumenty te odnalazł na strychu domu, w którym do 1923 roku, mieszkał Aleksander Patkowski. Tak o tym mówi: „Te papiery (...) były przynajmniej chwilami kompletne i było tego sporo. Korespondencji było sporo, np. listy do matki, listy od prof. Borowego do Patkowskiego"27. Stanowiły one tym bardziej cenne odkrycie, bowiem wszystko, co zebrał Patkowski

24 J. Smuniewska, Historia muzeum, http://www.zamek-sandomierz.pl/muzeum/historia-muzeum [dostęp: 8.05.2021]. W 1986 r. zbiory i siedzibę Muzeum przeniesiono do sandomierskiego zamku.

25 R. Stawowy, Oddział Literatury im. Jarosława Iwaszkiewicza i Dziat Literatury Muzeum Okręgowego w Sandomierzu - zarys historii, Kraków 2020, s. 9; maszynopis pracy dyplomowej w zbiorach Działu Literatury Muzeum Okręgowego w Sandomierzu. Poszerzona wersja pracy ukaże sie drukiem staraniem Wydawnictwa Diecezjalnego i Drukarni w Sandomierzu - Renata Stawowy, Muzeum Literatury $w$ Sandomierzu. Zarys historii Oddziału im. Jarosława Iwaszkiewicza i Działu Literatury Muzeum Okręgowego w Sandomierzu, Sandomierz 2021.

${ }^{26}$ Oddział Literatury zorganizował kilkanaście wystaw upamiętniających życie i twórczość m.in. Romana Koseły, Edwarda Szylko, Stanisława Młodożeńca, Witolda Gombrowicza, Wiesława Myśliwskiego (R. Stawowy, Oddział Literatury im. Jarosława Iwaszkiewicza i Dział Literatury Muzeum Okręgowego w Sandomierzu - zarys historii, Kraków 2020, s. 15).

27 By pozostał ślad... Wywiad z Jerzym Krzemińskim wieloletnim kierownikiem Oddziału Literatury im. Jarosława Iwaszkiewicza i kustoszem Dział Literatury Muzeum Okręgowego w Sandomierzu, w: R. Stawowy, Oddział Literatury im. Jarosła- 
w Warszawie, „spłonęło w Powstaniu Warszawskim, w jego mieszkaniu przy ulicy Narbutta". ${ }^{28}$

Do 1981 roku jedyne nieliczne materiały źródłowe dotyczące osoby Patkowskiego znajdowały się przede wszystkim w Bibliotece Narodowej. Odkrycie Jerzego Krzemińskiego i jego współpracownika dokonane na strychu dawnego domu Patkowskiego w Sandomierzu stanowi podstawę zbioru Działu Literatury Muzeum Okręgowego w Sandomierzu i jest prawdopodobnie największym zbiorem materiałów rękopiśmiennych, korespondencji oraz fotografii. Zatem dla podjętych rozważań istotne jest pytanie: Jaki materiał źródłowy zgromadzony został w Dziale Literatury Muzeum Okręgowego w Sandomierzu? oraz które ze zgromadzonych archiwaliów pozwolą na uzupełnienie wiedzy dotyczącej życia i działalności oświatowej Patkowskiego?

\section{Materiały źródłowe do biografii Aleksandra Patkowskiego}

Źródła do biografii są niezwykle istotne, bowiem to dzięki nim możliwe staje się zdobycie podstawowej wiedzy o życiu jednostki w określonym czasie historycznym. W badaniach biograficznych istotne znaczenie mają zarówno te źródła, które można zaliczyć do grupy materiałów cudzych oraz materiałów osobistych. Według Grzegorza Michalskiego do tej pierwszej należą: „prace biograficzne powstałe wcześniej, akty urzędowe, pamiętniki osób trzecich, dokumenty wywołane, dokumenty wizualne i audiowizualne, nekrologii i wspomnienia pośmiertne”29. Natomiast w skład materiałów osobistych należy zaliczyć: „au-

wa Iwaszkiewicza i Dział Literatury Muzeum Okręgowego w Sandomierzu - zarys historii, Kraków 2020, s. 38.

${ }^{28}$ J. Krzemiński, Trochę o rzeczach, trochę o ludziach, w: $W$ hołdzie Aleksandrowi Patkowskiemu (w setna rocznice urodzin), red. J. Grzywna, A. Rembalski, Kielce 1991, s. 195.

${ }^{29}$ G. Michalski, Źródła do badań biograficznych w historii wychowania, w: Konteksty i metody $w$ badaniach historyczno-pedagogicznych, red. T. Jałmużna, I. Michalska, G. Michalski, Kraków 2004, s. 174-175. 
tobiografię, pamiętniki i dzienniki, listy, kalendarze, notatki, dorobek twórczy"30.

W zbiorach Działu Literatury zgromadzony został przede wszystkim materiał osobisty. Wskazać tu należy przede wszystkim dzienniki. Pierwszy z nich to dziennik pisany w czasach studenckich, podczas pobytu Patkowskiego w Krakowie. Młody student zatytułował go Prace $i$ dnie. Pierwszego wpisu dokonał 17 listopada 1913 roku, a ostatni wpis widnieje pod datą 12 listopada 1914 roku. Dziennik ten jest swoistym rodzajem zapisu rozmyślań Patkowskiego nad dniem codziennym. Pod datą 19 grudnia 1913 roku, czyli już po uzyskaniu absolutorium, zanotował: „Dobiega koniec nowego etapu w pobycie moim w Krakowie i wszystkich rzeczy zebranie... na jakie drogi kieruje się moich pra-

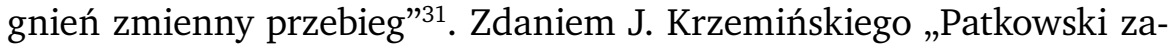
wsze miał potrzebę notowania myśli, spraw i zdarzeń z własnego życia"32. W zbiorach Działu znajdują się również dzienniki pochodzące z lat 1938-1940 33 . W zachowanych trzech tomach znajdujemy skrupulatnie zanotowany, z rozpisaniem na godziny, a nawet minuty, rozkład każdego dnia roku. Zawarte tam informacje ukazują człowieka niezwykle zajętego, pochłoniętego pracą i wykonywaniem codziennych obowiązków. Można odnieść wrażenie, że w życiu Patkowskiego nie było miejsca na nudę czy rozrywkę - chyba, że do tej ostatniej zaliczyć można przeglądanie prasy. Na tym etapie badań informacje zawarte w dziennikach mogą być pomocne do odtworzenia rytmu, a nawet codziennego rytuału dnia Patkowskiego. W dalszych badaniach mogą posłużyć do naszkicowania kontaktów osobistych i zawodowych Patkowskiego, wymagało to będzie dalszych wnikliwych badań i poszukiwań również w innych zasobach archiwalnych. W teczce o sygnaturze nr 193 znajdują się również kalendarze - Kalendarzyk robotniczy

30 Tamże, s. 178.

31 A. Patkowski, Prace i dnie, Muzeum Okręgowe w Sandomierzu, Dział Literatury sygn. 193/2 (MLS 728), s. 109; [dalej: MOS, DL].

32 J. Krzemiński, Trochę o rzeczach, trochę o ludziach, w: W hołdzie Aleksandrowi Patkowskiemu (w setna rocznice urodzin), red. J. Grzywna, A. Rembalski, Kielce 1991, s. 197.

33 Dzienniki 1938, 1939, 1940, MOS, DL sygn. 275. 
z 1918 roku z notatkami oraz luźne kartki z kalendarzyka (bez rocznej daty). W kalendarzach notował prawdopodobnie nazwy kolejnych spotkań. Pod datą 10 maja zanotował: „Rada Pedagogiczna, Redakcja „Spójni”; Wydz. Wyznań Oddziału”, a 23 września „Zarząd Ogniska". Te krótkie adnotacje pozwalają zorientować się przede wszystkim o liczbie podejmowanych aktywności, także tych o charakterze pedagogicznym $^{34}$. Obok dzienników i kalendarzy w zbiorach działu znajdują się notatki, część z nich datowana, zatem można wstępnie określić, że zawierają one zapisy z wykładów uniwersyteckich, z czasów krakowskich - Patkowski wymienia również nazwy kursów, temat wykładu, nazwisko wykładowcy, a czasem zalecaną do studiowania lekturę. W drugiej teczce zgromadzone są luźne kartki, bez podania daty, na których Patkowski robił notatki dotyczące np. przeczytanego artykułu. Zachowane w tej teczce rewersy z Biblioteki Jagiellońskiej, pozwalają sądzić, że są to notatki z czasów studenckich i prawdopodobnie obejmują lata 1911-1913³5. Istotnym materiałem źródłowym w pracy nad biografią mogą być zachowane dokumenty związane z dorobkiem twórczym. W zasobach Działu znajdują się: dokumenty związane przede wszystkim z jego działalnością nauczycielską - dokumenty dotyczące gmin szkolnych czy konspekty lekcji w liczbie $18^{36}$. W zbiorach zgromadzone są również dowody licznych wystąpień i odczytów Patkowskiego. Ponadto znajdują się tu rękopisy m.in. rękopis odpowiedzi na artykuły Feliksa Konecznego dotyczące pajdokracji i drukowane na łamach „Słowa” w 1912 roku $^{37}$. I jak zaznacza pierwszy kustosz Działu Literatury „Patkowski, nim stał się regionalistą, był krytykiem literackim i eseistą („Apostoł nierozsądku”, rękopis o Chesterto-

34 Kalendarzyk robotniczy 1918 r. z notatkami, MOS, DL sygn. 193/3 (MLS/729).

35 Dziennik pracy. Raptularz 1913, MOS, DL sygn. 193; Notatki, MOS, DL sygn. (MLS/737).

36 Tematyka poszczególnych konspektów dotyczy m.in. postaci i dzieł: Mikołaja Reja, Andrzeja Frycza-Modrzewskiego, Adama Naruszewicza, ale także tła historycznego i stanu oświaty w czasach porozbiorowych. Konspekty, MOS, DL sygn. 196/2.

37 A.K. Patkowski, Memo: orientacja polityczna a ideologia (w obronie nonsensu pajdokracji), MOS, DL sygn. (MLS/697). 
nie z 1915 roku), tłumaczem („Książę Homburgu” Kleista z 1910 roku i „Magia” Chestertona w rękopisie z ok. 1917 roku), wreszcie autorem jednoaktowych scenek dramatycznych, pisanych głównie dla potrzeb sandomierskiej sceny amatorskiej" ${ }^{38}$. Należy zaznaczyć, że Dział Literatury posiada również drukowane programy i plakaty amatorskich przedstawień teatralnych wystawianych na rzecz lokalnych organizacji czy instytucji ${ }^{39}$. Ostatnią grupą dokumentów zaliczanych do materiałów osobistych jest korespondencja. Do korespondencji zaliczyć należy nie tylko listy, kartki pocztowe, telegramy, ale także pisma urzędowe. Korespondencja, a szczególnie listy, może ukazać nam osobę w relacji z innymi. Ponadto możemy pośrednio otrzymać wiedzę dotyczącą kontaktów postaci, zarówno tych utrzymywanych z rodziną, kolegami, jak i tą o charakterze bardziej urzędowym ${ }^{40}$. W zbiorach Działu przechowywana jest liczna korespondencja, przede wszystkim ta adresowana do Patkowskiego, zarówno od przyjaciół np. Wacława Borowego (kolekcja listów tylko od Borowego liczy ok. 140 listów i kart pocztowych - ,ich ton, myśli, poruszane sprawy, wreszcie rozmiary dowodziły związków silnych i istotnych"41 oraz od drugiego kolegi czasów uniwersyteckich Karola Zawodzińskiego), jak też od dawnych nauczycieli akademickich Patkowskiego - Ignacego Chrzanowskiego, Romana Dybowskiego i Stanisława Windakiewicza. Osobne miejsce zajmują listy pisane do rodziców. Według Danuty Paszkowskiej „prywatna korespondencja Patkowskiego z matką odsłania portret, którego nie odnajdzie-

38 J. Krzemiński, Trochę o rzeczach, trochę o ludziach, w: W hołdzie Aleksandrowi Patkowskiemu (w setna rocznicę urodzin), red. J. Grzywna, A. Rembalski, Kielce 1991, s. 197.

39 Np. na rzecz towarzystwa dobroczynności, straży ogniowej MOS, DL sygn. 786

40 W. Szulakiewicz, Korespondencja $w$ badaniach historii edukacji $i$ nauki, w: Badania historyczne w pedagogice. Konteksty źródłowe, red. W. Szulakiewicz, Toruń 2015, s. 26-27, zob. również D. Kocurek, Korespondencja źródłem do badań biograficznych na przykładzie listów ks. dra Józefa Knosały, „Biografistyka Pedagogiczna", 2019 nr 1, s. 447-448.

41 J. Krzemiński, Trochę o rzeczach, troche o ludziach, w: W hołdzie Aleksandrowi Patkowskiemu (w setna rocznice urodzin), red. J. Grzywna, A. Rembalski, Kielce 1991, s. 196. Należy zaznaczyć, że w BN przechowywane są listy Patkowskiego do Borowego. BN rkps 7447 III. 
my na płaskorzeźbie czy w książkach, portret człowieka subtelnego, obdarzonego wielką wrażliwością syna, który starał się najbliższej osobie doradzać i której umiał okazać uczucia"42. Oprócz korespondencji prywatnej, w zbiorach znajdują się liczne listy urzędowe do Aleksandra Patkowskiego - m.in. od Dyrekcji Męskiej Szkoły Filologicznej z 1917, 1919 roku, od Dyrekcji gimnazjum w Jaśle, a także od Książnicy Polskiej z Lwowa w sprawie zamówionych przez Patkowskiego książek ${ }^{43}$.

Należy zaznaczyć, że Dział Literatury posiada również dokumenty zaliczane do tzw. materiałów cudzych i są to m.in. świadectwo z Uniwersytetu Lwowskiego, karat biblioteczna, umowy dotyczące prowadzenia zajęćc ${ }^{44}$, wspomnienia żony Patkowskiego ${ }^{45}$ oraz dokumenty wizualne. Ten ostatni rodzaj źródeł - fotografie pozwalają odkryć miniony świat, przywrócić pamięć o miejscu, wydarzeniach i wreszcie o osobach ${ }^{46}$. Fotografia jako źródło wizualne pozwala na poznanie ścieżek życia zarówno wybitnych jednostek, jak i tzw. zwyczajnych ludzi. W zbiorach Działu znajdują się fotografie rodzinne, np. zdjęcie Patkowskiego na werandzie domu z rodzicami i siostrami, Patkowski razem z kolegami, a także z późniejszego okresu pracy w szkole w otoczeniu uczniów i nauczycieli. Należy wspomnieć również o licznych zdjęciach z wycieczek, czy to rodzinnych czy zorganizowanych przez Państwowy Uniwersytet Regionalny ${ }^{47}$.

42 D. Paszkowska, Aleksander Patkowski mniej znany, w: W hołdzie Aleksandrowi Patkowskiemu (w setna rocznicę urodzin), red. J. Grzywna, A. Rembalski, Kielce 1991, s. 128. Korespondencja do rodziców, MOS, DL sygn. 144.

43 Listy urzędowe do Aleksandra Patkowskiego, MOS, DL sygn. 156 (156/7; $156 / 10 ; 156 / 86 ; 156 / 53)$.

${ }^{44}$ Dokumenty urzędowe i prywatne dotyczace spraw osobistych $i$ zawodowych Aleksandra Patkowskiego, MOS, DL, sygn. 166.

${ }^{45}$ Notatki do życiorysu Aleksandra Patkowskiego skreślone ręka Zofii Patkowskiej, MOS, DL, sygn. 277.

46 Zob. B. Topij-Stempińska, Obraz i fotografia jako źródło historyczne, w: Dzieło chwali mistrza. Księga jubileuszowa dedykowana prof. dr hab. Irenie Popiołek z okazji 50-lecia pracy artystycznej oraz pracy pedagogicznej, Kraków 2016, s. 243-252.

47 Fotografie rodzinne, MOS, DL sygn. 199, Album fotograficzny zawierający 375 zdjęć autorstwa Franciszka Uhorczaka z wycieczki Rodziny Regionalnej na Podole, MOS, DL sygn. 258. 


\section{Podsumowanie}

Nie ulega wątpliwości, że życie i działalność Aleksandra Patkowskiego zasługuje na przypomnienie. Wprawdzie powstało już wiele publikacji dotyczących życia, poglądów oraz pracy zawodowej i społecznej zasłużonego sandomierzanina, nie oznacza to jednak wyczerpania potencjału badawczego zawartego w materiale źródłowym tym znanym, ale możliwym jeszcze być może do odkrycia. Tym bardziej, że brakuje biografii Patkowskiego, takiej „całościowej, kompletnej” obejmującej wszystkie pola jego działalności. Materiały źródłowe przechowywane w Dziale Literatury Muzeum Okręgowego w Sandomierzu związane z osobą Aleksandra Patkowskiego to w dużej części dokumenty, które pozwolą dopełnić wizerunek sandomierskiego regionalisty, nauczyciela i działacza oświatowego. Na ich podstawie możliwe będzie uchwycenie portretu młodego studenta, nauczyciela i działacza oświatowego.

Warto dodać, że o znaczeniu Patkowskiego dla miasta świadczą nie tylko podejmowane badania naukowe, ale również inicjatywy społeczności lokalnej. W mieście rodzinnym wmurowano tablicę upamiętniającą Patkowskiego - regionalistę, a od 1998 roku przyznawana jest nagroda im. A. Patkowskiego, której celem ,jest zachęta do kontynuowania działań indywidualnych i zbiorowych, nawiązujących do dorobku i osiągnięć Aleksandra Patkowskiego, współtwórcy polskiego regionalizmu, wyzwalanie aktywnego stosunku wobec własnego środowiska, rozwijanie badań z zakresu przeszłości i kultury regionu, utrwalanie odrębności lokalnych oraz popularyzacja tzw. małych ojczyzn"48.

48 Regulamin nagrody „Bonum Publicum” http://www.zamek-sandomierz.pl/ kontakt/31-rozne/5-bonum-publicum-nagroda-burmistrza-miasta-sandomier za-im-aleksandra-patkowskiego [dostęp: 9.06.2021]. 


\section{Bibliografia:}

\section{Źródła}

\section{Dziat Literatury Muzeum Okręowego w Sandomierzu}

Album fotograficzny zawierający 375 zdjęć autorstwa Franciszka Uhorczaka z wycieczki Rodziny Regionalnej na Podole, sygn. 258.

Dokumenty urzędowe $i$ prywatne dotyczace spraw osobistych $i$ zawodowych Aleksandra Patkowskiego, sygn. 166.

Dziennik pracy. Raptularz 1913, sygn. 193.

Dzienniki 1938, 1939, 1940, sygn. 275.

Fotografie rodzinne, sygn. 199.

Kalendarzyk robotniczy 1918 r. z notatkami, sygn. 193/3 (MLS/729).

Konspekty, sygn. 196/2.

Korespondencja do rodziców, sygn. 144.

Listy urzędowe do Aleksandra Patkowskiego, sygn. 156 (156/7; 156/10; 156/86; 156/53).

Notatki, sygn. (MLS/737).

Notatki do życiorysu Aleksandra Patkowskiego skreślone ręką Zofii Patkowskiej, sygn. 277.

Patkowski A., Prace i dnie, sygn. 193/2 (MLS 728), s. 109.

Patkowski A.K., Memo: orientacja polityczna a ideologia ( $w$ obronie nonsensu pajdokracji), sygn. (MLS/697).

Program przedstawienia amatorskiego na rzecz Sandomierskiego Towarzystwa Dobroczynności 1908 r., syg. 786/2.

Stawowy R., Oddział Literatury im. Jarosława Iwaszkiewicza i Dziat Literatury Muzeum Okręgowego w Sandomierzu - zarys historii, Kraków 2020, maszynopis pracy dyplomowej.

\section{Opracowania:}

Banaczkowski, Piotr. „Aleksander Patkowski”. Ziemia Kielecka 1 (1956): 3.

Banaczkowski, Piotr. „Aleksander Patkowski”. Ziemia 1-2 (1945): 4-5.

Banaczkowski, Piotr. „Aleksander Patkowski. Zarys życia i pracy”, w: A. Patkowski, $W$ hołdzie dla ziemi rodzinnej, 11-39. Warszawa: Ludowa Spółdzielnia Wydawnicza, 1958. 
Bednarz, Irena, „Aleksander Patkowski (1890-1942)”. Studia Kieleckie 3 (1975): 89-92.

Bień A., Bóg wysoko - dom daleko: obrazy przeszłości 1900-1920, Warszawa: Ludowa Spółdzielnia Wydawnicza, 1984.

Borowy, Wacław. „Aleksander Patkowski”. Pamiętnik Literacki 3-4 (1946): 309-312.

Corpus studiosorum Universitatis Iagellonicae in saeculis XVIII-XX, t. 3, O-Q, red. K. Stopka, 234. Kraków: Towarzystwo Wydawnicze „Historia Iagellonica, 2011.

Czajka, Michał, Kamler, Marcin, Sienkiewicz, Witold. „Aleksander Patkowski", w: Leksykon historii Polski, red. Michał Czajka, Marcin Kamler, Witold Sienkiewicz, 550. Warszawa Wiedza Powszechna, 1995.

Giergiel, Tomisław. „Dziedzictwo przodków. Pochodzenie Aleksandra Patkowskiego", w: Twórca polskiego regionalizmu. Nowe badania nad życiem i działalnościa Aleksandra Patkowskiego, red. Tomisław Giergiel, 75-100. Sandomierz: Oddział Polskie Towarzystwo Turystyczno-Krajoznawcz, Oddział Polskie Towarzystwo Historyczne, 2015.

Grzywna, Józef, Jadach Jan. „Aleksander Patkowski (1890-1942)”, w: W hozdzie Aleksandrowi Patkowskiemu (w setna rocznicę urodzin), red. Józef Grzywna, Andrzej Rembalski, 6-17. Kielce: WSP im. Jana Kochanowskiego w Kielcach, 1991.

Jałmużna, Tadeusz. „Aleksander Patkowski - regionalizm i wychowanie społeczne". W: Pokój jako przedmiot badań społecznych i pedagogicznych, red. Wiesława Leżańska, Tadeusz Jałmużna, 106-111. Łódź: Wyższa Szkola Informatyki, 2006.

Kocurek, Danuta. „Korespondencja źródłem do badań biograficznych na przykładzie listów ks. dra Józefa Knosały”. Biografistyka Pedagogiczna 1 (2019): 445-457.

Koźmian, Danuta. „Oświata pozaszkolna na tle założeń regionalizmu Aleksandra Patkowskiego (1890-1942)". W: Z praktyki polskiej teorii i praktyki andragogicznej, red. Eleonora Sapia-Drewniak, Agieszka Stopińska-Pająk, 168-181. Toruń: Wydawnictwo Adam Marszałek, 1997.

Koźmian, Danuta. Poglądy społeczno-pedagogiczne Aleksandra Kazimierza Patkowskiego (1890-1942). Szczecin: Wydawnictwo Naukowe US, 1994.

Krzemiński, Jerzy. „Trochę o rzeczach, trochę o ludziach”, w: W hołdzie Aleksandrowi Patkowskiemu (w setnq rocznicę urodzin), red. Józef Grzyw- 
na, Andrzej Rembalski, 193-198. Kielce: WSP im. Jana Kochanowskiego w Kielcach, 1991.

Lipowski, Wojciech. „Wspomnienie o Patkowskim”. Ożarów 4 (2000): 20-21. Łowicka, Mariola. „Portret Aleksandra Patkowskiego”. Notatnik Sandomierski 7 (1995): 32-37.

Łoza, Stanisław. Czy wiesz kto to jest?, Warszawa: Wydawnictwo Głównej Księgarni Wojskowej, 1938.

Michalski, Grzegorz. „Źródła do badań biograficznych w historii wychowania". W: Konteksty $i$ metody $w$ badaniach historyczno-pedagogicznych, red. Tadeusz Jałmużna, Iwonna Michalska, Grzegorz Michalski, Kraków: Impuls, 2004.

Paszkowska, Danuta. „Aleksander Patkowski mniej znany”. W: Twórca polskiego regionalizmu. Nowe badania nad życiem i działalnością Aleksandra Patkowskiego, red. Tomisław Giergiel, 123-135. Sandomierz: Oddział Polskie Towarzystwo Turystyczno-Krajoznawcz, Oddział Polskie Towarzystwo Historyczne, 2015.

Paszkowska Danuta. „Aleksandra Patkowskiego rozmowy z Matuśką”, w: Hieronimki, red. Barbara Tęgiewicz, Krzysztof Zieliński, 63-69. Sandomierz: Towarzystwo Naukowe Sandomierskie 2016.

Patkowski Aleksander, w: Stownik biograficzny prekursorów turystyki oraz działaczy PTT, PTK i PTTK, Warszawa: Wydawnictwo PTTK „Kraj”, 1988.

Regulamin nagrody „Bonum Publicum, ” http://www.zamek-sandomierz.pl/ kontakt/31-rozne/5-bonum-publicum-nagroda-burmistrza-miasta-sando mierza-im-aleksandra-patkowskiego (dostęp: 9.06.2021).

Rembalski, Andrzej, Wójcik Zbigniew. „Aleksander Patkowski”, w: Polski słownik biograficzny, t. 25, 332-334. Wrocław-Warszawa-Kraków-Gdańsk: Ossolineum, 1980.

Sawicki, Ludwik. „Muzeum P.T.K. w Sandomierzu”. Ziemia 15-18 (1930): 339.

Sławiński, Piotr. „Sandomierskie lata Aleksandra Patkowskiego”, w: Twórca polskiego regionalizmu. Nowe badania nad życiem i działalnościa Aleksandra Patkowskiego, red. Tomisław Giergiel, 101-109. Sandomierz: Oddział Polskie Towarzystwo Turystyczno-Krajoznawcz, Oddział Polskie Towarzystwo Historyczne, 2015.

Smuniewska, Jolanta. Historia muzeum, http://www.zamek-sandomierz.pl/ muzeum/historia-muzeum (dostęp: 8.05.2021).

Sprawozdanie z działalności w roku 1921, Warszawa: 1922. 
Szulakiewicz, Władysława. Korespondencja $w$ badaniach historii edukacji i nauki, W: Badania historyczne w pedagogice. Konteksty źródłowe, red. Władysława Szulakiewicz, 25-53. Toruń: Wydawnictwo Naukowe UMK, 2015.

Szulakiewicz, Władysława. „Ego-dokumenty i ich znaczenie w badaniach naukowych". Przeglą Badań Edukacyjnych 16 (2013): 65-84.

Szylko, Edward. Działalność Powszechnego Uniwersytetu Regionalnego im. St. Konarskiego Związku Nauczycielstwa Polskiego w latach 1922-1930. W: Pamiętnik Świętokrzyski 1930, red. Aleksander Patkowski, 401-403. Kielce: Wydawnictwo Wydziału Wojewódzkiego i Sekcji Regionalistycznej ZNP, 1931.

Topij-Stempińska, Beata. Obraz i fotografia jako źródło historyczne, w: Dzieło chwali mistrza. Księga jubileuszowa dedykowana prof. dr hab. Irenie Popiotek z okazji 50-lecia pracy artystycznej oraz pracy pedagogicznej, red. Anna Królikowska, Marek Łatkowski, Beata Topij-Stempińska, 243-252. Kraków: Wydawnictwo Akademii Ignatianum, 2016.

Wojciechowski S., Patkowski Aleksander Kazimierz, w: Słownik pracowników ksiązki polskiej, red. Irena Treichel, 662. Warszawa-Łódź: Państwowe Wydawnictwo Naukowe: 1972.

Wójcik, Zbigniew. Aleksander Patkowski pionier regionalizmu turystyczno-krajoznawczego w Polsce, Radom: Prywatna Wyższa Szkoła Ochrony Środowiska, 2003.

Załuska, Kamilla. „Historia Muzeum w Sandomierzu”. Rocznik Muzeum Świętokrzyskiego 5 (1968): 9-28.

Żołądź-Strzelczyk Dorota, Jamrożek Wieslaw. „Edukacja regionalna w ujęciu Aleksandra Patkowskiego", w: Edukacja regionalna, red. Anna Weronika Brzezińska, Aleksandra Hulewska, Justyna Słomska, 115-130. Warszawa: Wydawnictwo Naukowe PWN 2006. 